\title{
Deep deformations of the upper stream of a low- pressure reservoir
}

\author{
Dilshod Bazarov ${ }^{1 *}$, Irina Markova ${ }^{2}$, Sukhrob Umarov ${ }^{1}$, Khumoyun Raimov ${ }^{1}$, and Azizali \\ Kurbanov $^{1}$ \\ ${ }^{1}$ Tashkent Institute of Irrigation and Agricultural Mechanization Engineers, Tashkent, Uzbekistan \\ ${ }^{2}$ Moscow State University of Civil Engineering, Moscow, Russia
}

\begin{abstract}
The article presents the results of the analysis of the deep deformations of the Amu Darya riverbed in the upper reaches of the lowpressure reservoir. The analysis of the combined transverse profiles of the riverbed in different sections of the upper reaches of the Takhiatash reservoir showed that the coastal zones are most intensively silted up. At the same time, the core zone with the highest flow rates is very weakly declared. The height of the silting layer along the length of the upper stream increases in the direction of the dam. The silting area extends upstream for a length 2-3 times longer than the length of the soundings section, which is $17.5 \mathrm{~km}$. To ensure the normal operation of the hydraulic system, it is recommended that conditions should be created for a normal and stable approach of the flow to the hydraulic system, which should be ensured by maneuvering the shield holes. To do this, it is necessary to create conditions for the erosion of the left-bank spillway by increasing the water flow through the extreme left-bank discharge holes. Flushing of the upper left-bank section of the river should continue until the optimal width of the leading channel is reached, which provides the main flow of the stream in front of the structure. It is proved that the formation and development of sediment deposits on the right bank between sections 8-10 leads to a change in the flow correction and creates conditions for the formation of shoals in front of the regulator of the Kizketken channel, which can complicate the operation of the water intake zone. Therefore, it is necessary to take measures to prevent the development of the right-bank channel, and the development of the channel should go from the main channel. As shown by monitoring operating mode Takhiatash waterworks, in the Takhiatash district waterworks intensive processes the channel formation, which has a strong influence on the operational mode of the dam, especially in the operation of the water intakes flushing of sediments, skip flood costs through the shields of the dam and the stability of structures.
\end{abstract}

*Corresponding author: dr.bazarov@mail.ru 


\section{Introduction}

The object of the study is the upper stream of the Takhiatash hydroelectric complex, which was built in the lower reaches of the Amu Darya River in 1974 and is located $215 \mathrm{~km}$ from the former mouth of the Amu Darya River. The operational mode of the hydroelectric facility depends on the working conditions of the Tuyamuyun reservoir.

During the operation of the Takhiatash of the dam, the upstream depth is intense deformation, causing the rise of the seabed and water levels at great length, which reduces the useful volume of the reservoir and makes the condition of the dam. Due to a sharp change in the hydrological regime of the river and an increase in the degree of its regulation in the upper reaches, the process becomes more intense and irreversible [1,2]. In addition, the operating mode of the Tuyamuyun reservoir, a hydroelectric complex located $241 \mathrm{~m}$ from the former mouth of the Amu Darya River, significantly affects the flow processes of the object under study [3-6]. Basically, the most characteristic intensive channel deformations for the upper reaches of reservoirs are siltation and sedimentation in the upper reaches of the hydroelectric complex [7-9]. As a result of silting and entering the upper stream, the volume of the useful volume of the reservoir decreases, and difficulties arise in the operation of the water intake structures of the hydroelectric complex [10-12]. This fact significantly complicates the operating conditions of the hydroelectric power plant. Therefore, the study of the channel environment, the intensity of deep deformations, and their nature, the direction of channel processes is considered an urgent task of channel hydraulics.

As you know, the study of the issues of channel processes due to the multifactorial nature and multidirectional in space and time is presented as one of the complex tasks of channel hydraulics [13-17].

Finding out the actual course of the processes of reforming the reservoirs of dam waterworks is of great importance for the organization of their proper operation. One of the main problems is a sharp decrease in the useful volume of the reservoir due to the siltation of its bowl. Many scientists have been studying the intensity of siltation of the upper reaches of reservoir hydroelectric units. To improve the operating conditions of the Takhiatash reservoir hydroelectric complex, field studies of the re-formation were started immediately after its commissioning in 1973 and continue to the present day [6, 14, 18, 19]. Although, to date, made multiple field observations and offered many recommendations for improving slove operation, due to the change of operating mode tuyamuyunskoe reservoir and mode of the Amu Darya river, improving the degree of regulation of the upper reaches of the river, the depth of deformation of the river in the area of the object of study is unstable. Based on the above, the determination of the nature of deep deformations and the development of recommendations for improving the operating conditions of the hydroelectric power plant is defined as the main goal of this work [20-29].

\section{Methods}

The study of the results of field studies, processing of materials, and based on the analysis of the obtained results to develop recommendations for improving the condition of operation of the object of study is adopted as a method of the research of this work.

\section{Results and Discussion}

As the results of field studies have shown, the dynamics of water flow in the upper reaches of the Takhiatash low-pressure reservoir are characterized by sharp variability. 


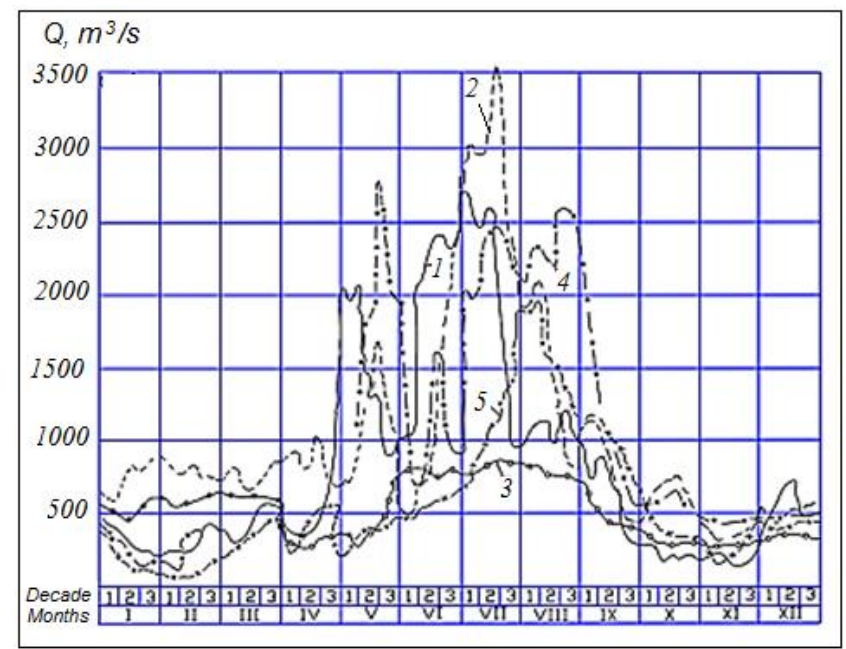

Fig. 1. Changes in water flow rates of the Amu Darya River upstream of the Takhiatash reservoir: 1 is year of observation, 2 is year of observation, 3 is year of observation, 4 is year of observation, 5 is year of observation.

Because of this, intense deformations occur in the study area. Observations of the course of sediment deposition in the upstream showed that during the flood period, deep sections of the riverbed are brought in by sediments and shallow ones, on the contrary, deepen. In the low-water period, the small ones are reversed.
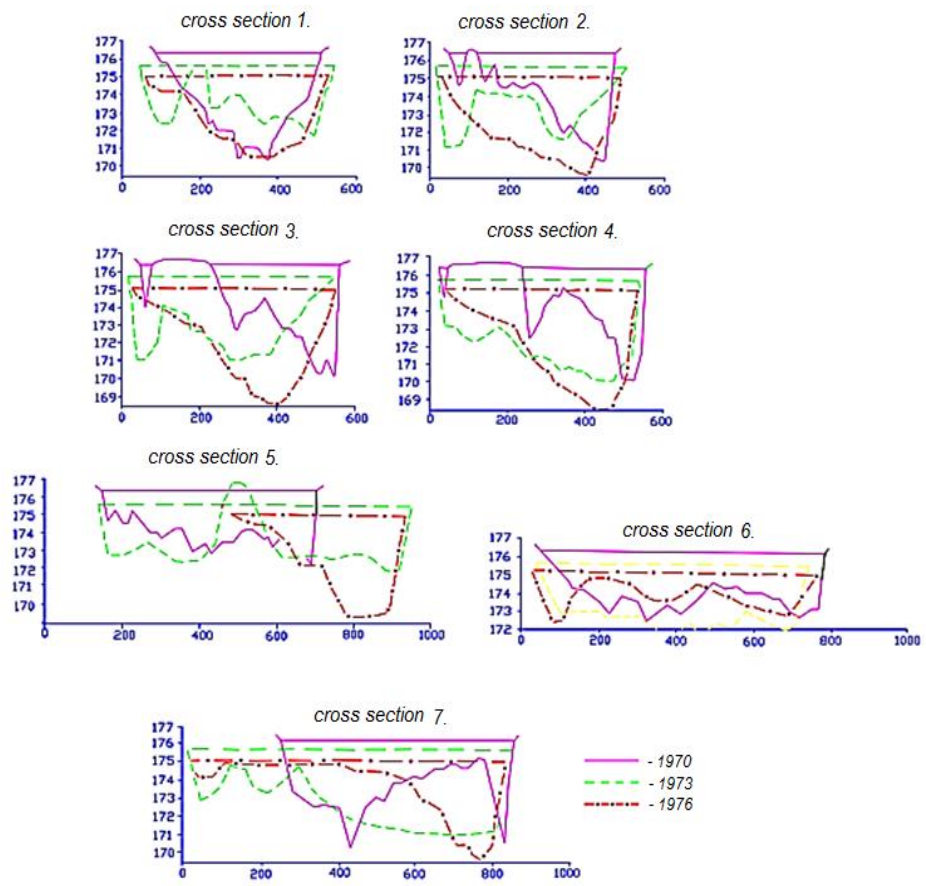

Fig. 2. Combined transverse profiles of the riverbed in different sections of the upper reaches of the Takhiatash reservoir. 

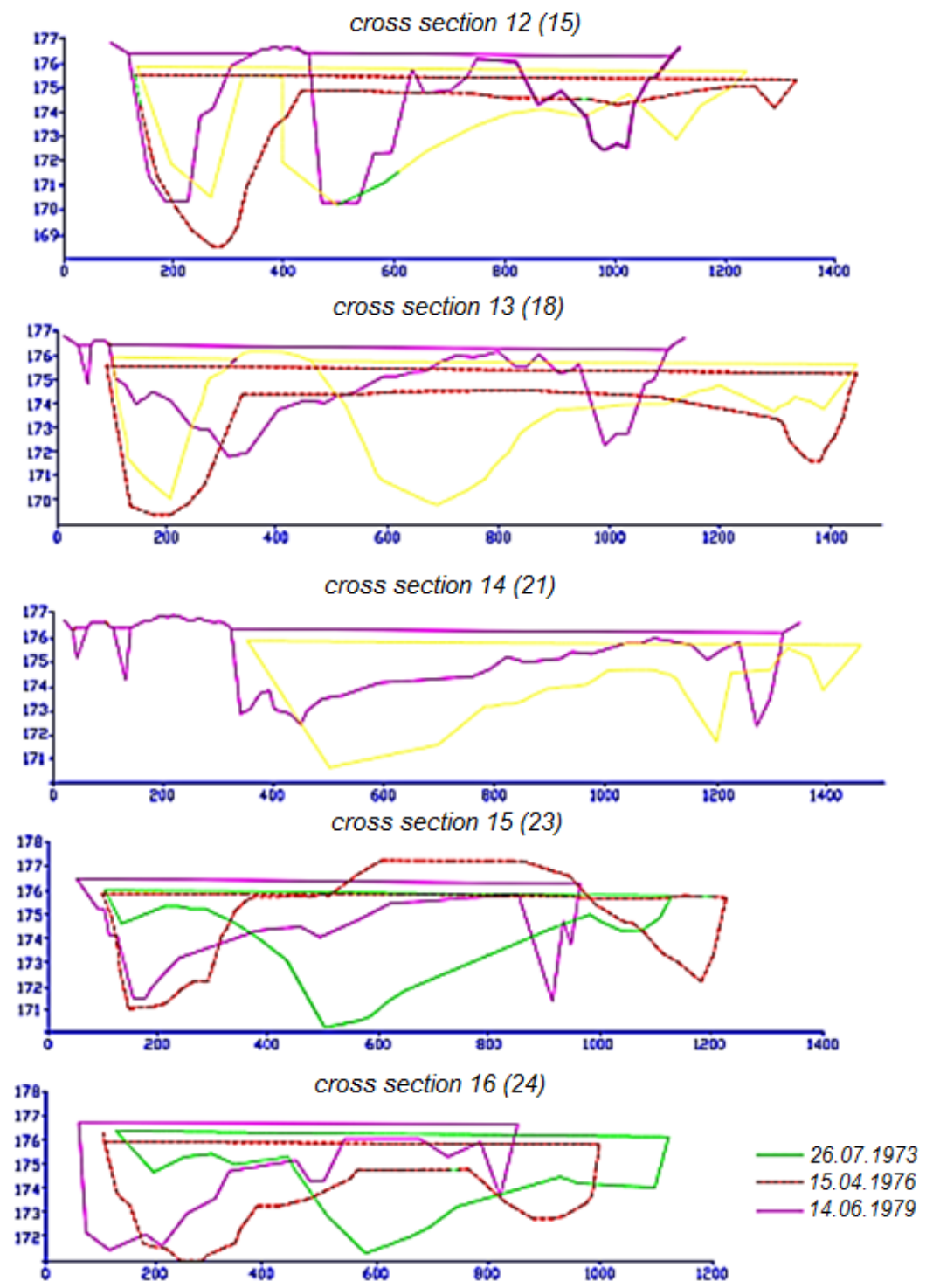

Fig. 3. Combined transverse profiles of the riverbed in different sections of the upper reaches of the Takhiatash reservoir

As can be seen from Figures 2, 3, intensive silting is observed in shallow and coastal zones, and the channel is deepened along the fairway of the river. The bulk of the sediment settles where the river has a wide channel. Sediment deposition is distributed unevenly across the width of the riverbed and floodplain. The coastal zones are silted up most intensively, while the core zone with the highest flow rates is silted up very weakly. The height of the silting layer along the length of the upper stream increases in the direction of the dam. 


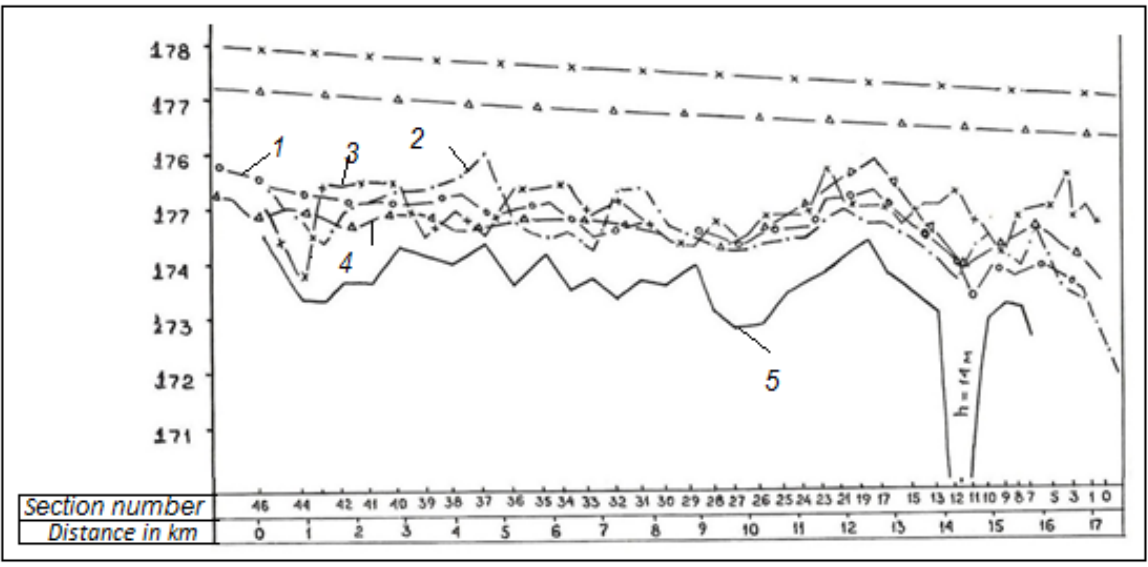

Fig. 4. Changes in the bottom level at different sections of the upstream dam at a length of $17.5 \mathrm{~km}: 1$ is the year of observation in; 2 is after 1 year; 3-10 are years after the first year of observation; 4-20 are years after the first year of observation; 5-25 are years after the first year of observation.

Figure 4 shows the longitudinal profiles of the river in the upper reaches of the dam at the average bottom marks, calculated from the data of soundings from different years of observation, where the siltation area extends upstream for a length 2-3 times greater than the length of the soundings section, which is $17.5 \mathrm{~km}$.

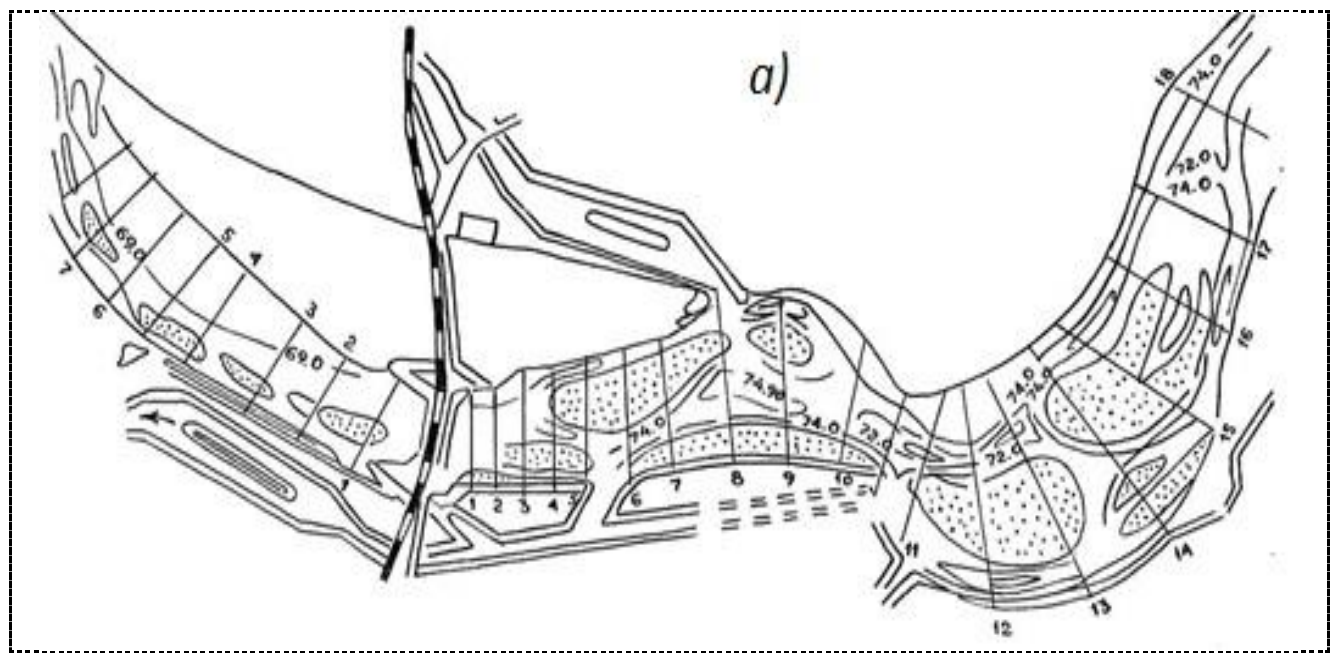




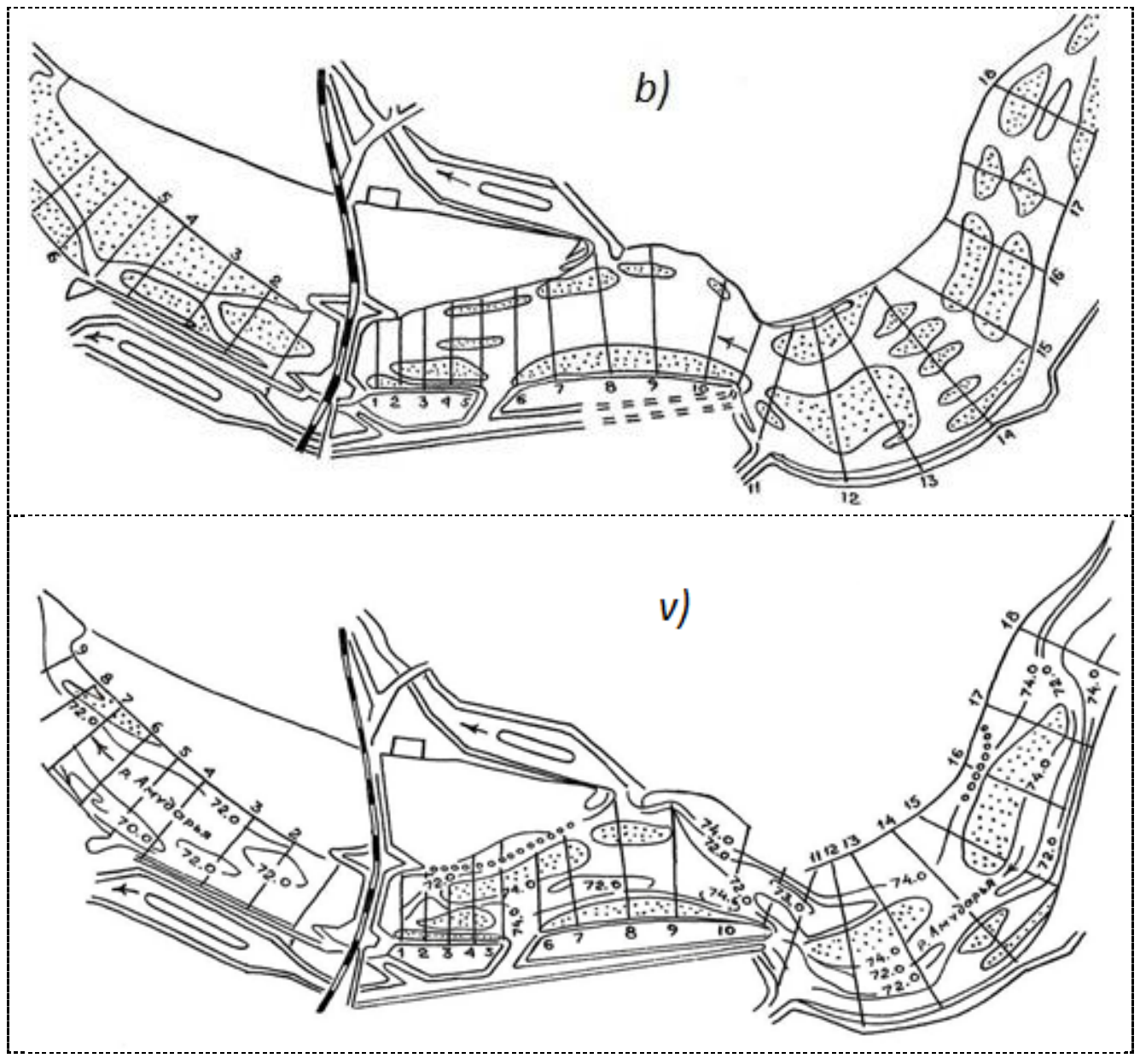

Fig. 5. Channel-forming processes in the streams of the Takhiatash hydroelectric complex on the Amu Darya River: a) 1996; b) 1997; v) 1998.

As a result of the reformation of the channel, the following channel formations appeared in the upper stream of the node (Figure 5). Along the right bank, there is a narrow washed channel with a length of $2.0 \mathrm{~km}$ due to the formation of a sharp flow dump on the approach to the pressure front. On the left side, a powerful shoal with a mark of up to $176.5 \mathrm{~m}$ (NPU mark - 177.2) was formed, occupying about half the width of the supply channel and continuing almost to the shield dam. There were also observed the formation of shoals in the extended part of the channel between the sections 12-18 at the right-bank streamguiding dam, which significantly restricts the supply channel. Currently, there is very straightening of the channel in the area of Takhiatash the bend, there is a gradual withdrawal of the core flow from the right concave shore, where the water intake canal Kyzketken and also happens undermining the spurs end-to-end stream directing dams № 2 and № 4, designed to create a transverse circulation. According to the above, the study area can be divided into different characteristic areas (Figure 6): 


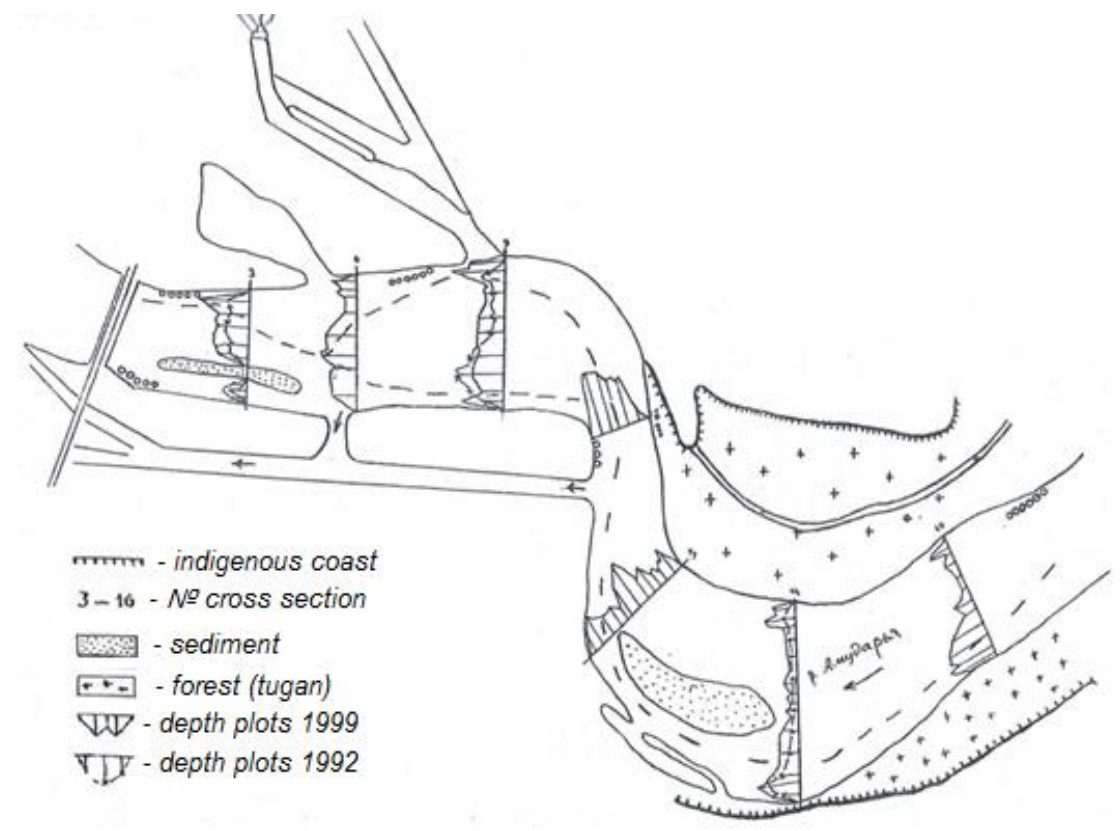

Fig. 6. A plan of the riverbed and riverbed formations with the indication of the boundaries of floodplain areas in the upper reaches of the dam on the section of the supply channel of the hydroelectric complex.

\section{Conclusions}

1. The analysis of the combined transverse profiles of the riverbed in different sections of the upper reaches of the Takhiatash reservoir showed that the coastal zones would be silted up most intensively, while the core zone with the highest flow rates will be silted up very weakly. The height of the silting layer along the length of the upper stream increases in the direction of the dam. The silting area extends upstream for a length 2-3 times longer than the length of the soundings section, which is $17.5 \mathrm{~km}$.

2. Analysis of the data of channel surveys for the period under review, previously conducted studies, as well as design and survey materials will allow for the technical and economic significance and hydro-morphological structure, the studied part of the upper stream, which is most affected by the waterworks, can be divided into four sections:

- the first section is part of the supply channel, between the shield dam and the temporary navigable slot in the combined channel (SCHP - stv. № 5). This section has the most intensive flushing in the depth of the channel during the flushing of the supply channel. The observational data shows that in this area, the course of the channel process strongly depends on the maneuvering of the gates and fluctuations in the water level. The most dangerous is the erosion of the bottom of the channel on the approach of the stream to the shield dam. The lowest levels of the bottom in August 1998 on the targets: №2 - 70.00, № $3-70.00$, № $4-70.40$, № $5-72.00$. Further observations showed that due to the decline of the flood, there is no danger of washing out the depressing part;

- the second section is part of the medu riverbed with a temporary navigable cut and Cape Tahiatash (stv. 6-10). On the right bank of this section is the water intake structure of the Kizketken canal, where there is intense channel deformation. During the observation period, there were significant deformations of the channel both in depth and in plan (the left-bank bend of the shoal in front of the structure expanded). The planned displacement 
was not significantly observed. The formed main channel pressed to the left bank continues to function, despite the flood flow passing through it;

- the third section-part of the supply channel is an artificially created curved channel, in which the jet-guiding character of Cape Takhiatash and the natural outline of the left-bank bend are used; the section ends at the upper border of the supply channel. In this area, there were significant channel deformations leading to self-straightening of the channel, where there was a movement of the main channel to the right, bypassing the curved artificially created part of the channel (here at Cape Tahiatash, there is a water intake of the Suenli Channel and a Parallel one). On (stv.12), the expanded places of the formed islets having three channels. The river's main stream flowing through the middle part of the island intensively erodes the right part of the island. The washout covers the entire length of the island and in width (about $300 \mathrm{~m}$ ) and in depth- $0.5 \mathrm{~m}$.

- the fourth section located upstream, within the limits of the 15-20-fold lines, is almost rectangular in plan. In this area, there were movements of small ridges and minor erosion of the bottom and banks. The measurement data show that despite the high flow velocities $v_{a v}=1.6 \mathrm{~m} / \mathrm{s}$ and the lower turbidity of the flow, no large bottom washouts were observed in this area;

3. Education left Bank side directly on the approach to the shield of the dam leads to a significant narrowing of the riverbed in this area (between sections $1-7$ ). Here the river shifted to the right bank, and the increase in costs is a sharp increase in the flow rate, is an intense process of erosion of the seabed and excessive turbidity flow, which is caused, apparently, partial opening, extreme holes adjacent to the right bank of the river in the process of operation shield of the dam. Further operation of the dam with the advantage of an open opening on the right bank side may result in deepening of the bottom and erosion of the bank on the front line along the protective right-bank through spurs, which is highly undesirable. Therefore, this area of erosion must be blocked by the construction of a longitudinal dam.

4. To ensure the normal operation of the hydraulic system, it is necessary to create conditions for a normal and stable approach of the flow to the hydraulic system, which should be ensured by maneuvering the shield holes. To do this, it is necessary to create conditions for the erosion of the left-bank side water by increasing the water flow through the extreme left-bank discharge holes. It is flushing the upper left-bank sidewalk by maneuvering the shield holes. To do this, it is necessary to create conditions for the erosion of the left-bank spillway by increasing the water flow through the extreme left-bank discharge holes. Flushing of the upper left-bank section of the river should continue until the optimal width of the leading channel is reached, which provides the main flow of the stream in front of the structure.

5. The formation and development of sediment deposits on the right bank between sections 8-10 leads to a change in the flow correction and creates conditions for the formation of shoals in front of the regulator of the Kizketken channel, which can complicate the operation of the water intake zone. Therefore, it is necessary to take measures to prevent the development of the right-bank channel, and the development of the channel should go from the main channel.

6. As the observations of the operational regime have shown, intensive riverbed formation processes occur in the area of the Takhiatash hydroelectric complex, which strongly affects the operational regime of the hydroelectric complex, especially the work of water intake structures, sediment washing, the passage of flood flows through the shield dam and the stability of structures. 


\section{References}

1. Bazarov D., Markova I., Raimova I., and Sultanov S. Water flow motion in the vehicle of main channels, IOP Conf. Ser. Mater. Sci. Eng. 883, 012001, (2020), DOI:10.1088/1757-899x/883/1/012001

2. Bazarov D., Shaazizov F., and Erjigitov S. Transfer of Amudarya flowing part to increase the supportability of the Uzbekistan southern regions, IOP Conf. Ser. Mater. Sci. Eng. 883, pp. 012068, (2020), DOI:10.1088/1757-899x/883/1/012068

3. Krutov A., Choriev R., Norkulov B., Mavlyanova D., Shomurodov A. Mathematical modelling of bottom deformations in the kinematic wave approximation. IOP Conf. Ser. Mater. Sci. Eng. 1030, pp. 012147 (2021), DOI:10.1088/1757899x/1030/1/012147

4. Krutov A., Norkulov B., Uljaev F., Jamalov F. Results of a numerical study of currents in the vicinity of a damless water intake, IOP Conf. Ser. Mater. Sci. Eng. 1030, pp. 012121, (2021), DOI:10.1088/1757-899x/1030/1/012121

5. Obidov, B., Vokhidov, O., Tadjieva, D., Saidkhodjaeva, D., Kurbanova, U., Isakov, A. Hydrodynamic effects on the flow elements of the downstream devices in the presence of cavitation, IOP Conf. Ser. Mater. Sci. Eng. (2021) 1030, pp. 012114, DOI:10.1088/1757-899x/1030/1/012114

6. Khidirov S., Jumaboeva G., Ishankulov Z. Hydraulic mode of operation of the Takhiatash hydroelectric complex. (2021), DOI:10.1088/1757-899X/1030/1/012120

7. Ergashev R., Ismoilov N., Nasirova N., Kholbutaev B., Khusanbayeva K., Nazarov O. Technology of water supply to water inlets of pumping stations. IOP Conference Series: Materials Science and Engineering, 1030, 012156 (2021), DOI:10.1088/1757899x/1030/1/012156.

8. Eshev S., Rakhimov A., Gayimnazarov I., Isakov A., Shodiev B., Bobomurodov F. Dynamically stable sections of large soil canals taking into account wind waves. IOP Conf. Ser. Mater. Sci. Eng. 1030, 012134, (2021), DOI:10.1088/1757899x/1030/1/012134.

9. Eshev S., Latipov S., Qurbonov A., Sagdiyev J., Berdiev M., Mamatov N. Noneroding speed of water flow of channels running in cohesive soils. IOP Conference Series: Materials Science and Engineering. 1030. 012131, (2021), DOI:10.1088/1757899x/1030/1/012131.

10. Glovatsky, O., Ergashev, R., Nasirova, N., Kholbutaev, B., Khusanbayeva, K. Estimation of the forecast of pump ready rate for reclamation systems, IOP Conference Series: Materials Science and Engineering, 1030(1), 012115, (2021)

11. Bazarov D., Uralov B., Matyakubov B., Vokhidov O., Uljaev F., Akhmadi M. The effects of morphometric elements of the channel on hydraulic resistance of machine channels of pumping stations, IOP Conf. Ser. Mater. Sci. Eng., 869(7), 2020, DOI:10.1088/1757-899X/869/7/072015

12. Matyakubov B., Begmatov I., Raimova I. and Teplova G. Factors for the efficient use of water distribution facilities. IOP Conf. Ser. Mater. Sci. Eng. 883, 012025 (2020)

13. Khidirov S., Norkulov B., Ishankulov Z., Nurmatov P., Gayur A. Linked pools culverts facilities. IOP Conf. Ser. Mater. Sci. Eng. 883, 012004, (2020), DOI:10.1088/1757-899x/883/1/012004

14. Ergashev, R., Ismoilov, N., Nasirova, N., ...Khusanbayeva, K., Nazarov, O. Technology of water supply to water inlets of pumping stations, IOP Conference Series: Materials Science and Engineering, 1030(1), 012156, (2021) 
15. Ergashev, R., Azizov, O., Dehkanova, N., Bozorov, A. Development of energy-saving modes of irrigation pump stations, IOP Conference Series: Materials Science and Engineering, 883(1), 012017, (2020)

16. Ergashev, R., Bekchanov, F., Akmalov, Sh., Shodiev, B., Kholbutaev, B. New methods for geoinformation systems of tests and analysis of causes of failure elements of pumping stations, IOP Conference Series: Materials Science and Engineering, 883(1), 012015, (2020)

17. Bazarov D., Vatin N., Bakhtiyor O., Oybek V. Hydrodynamic effects of the flow on the slab of the stand in the presence of cavitation. IOP Conf. Ser. Mater. Sci. Eng. 1030, 012110, (2021), DOI:10.1088/1757-899X/1030/1/012116

18. Dilshod B., Markova I., Sultanov S., Kattakulov F. Dynamics of the hydraulic and alluvial regime of the lower reaches of the Amudarya after the commissioning of the Takhiatash and Tuyamuyun hydrosystems. IOP Conference Series: Materials Science and Engineering. 1030, 012110, (2021), DOI:10.1088/1757-899X/1030/1/012110

19. Uralov B., Rakhmatov N., Khidirov S., Safarov G. Hydraulic modes of damless water intake. (2021) DOI:10.1088/1757-899X/1030/1/012123

20. Urishev B., Artikbekova F., Kuvvatov D., Nosirov F., Kuvatov U. Trajectory of sediment deposition at the bottom of water intake structures of pumping stations, IOP Conf. Ser. Mater. Sci. Eng. 1030, 012137, (2021), DOI:10.1088/1757899x/1030/1/012137

21. Uralov B., Choriev R., Maksudova L. Substantiation of the influence of the channel shape and the roughness of machine canals on the pressure loss of irrigation pumping stations Substantiation of the influence of the channel shape and the roughness of machine canals on the pressure loss of i. (2021), DOI:10.1088/1757899X/1030/1/012148.

22. Shokirov B., Norkulov B., Nishanbaev Kh., Khurazbaev M., Nazarov B. Computer simulation of channel processes. E3S Web of Conferences, 97, 05012, (2019)

23. Kan, E., Muratov, A., Yusupov, M., Ikramov, N. Calculation of water hammer on the pressure pipeline of modernized irrigation pumping station. IOP Conf. Ser. Mater. Sci. Eng., 1030, 012127, (2021), DOI:10.1088/1757-899x/1030/1/012127

24. Mukhamedov Y.S., M.O.Y. Ruslo- i nanosoreguliruyushchiye meropriyatiya pri vodozabore iz reki Amudar'i v magistral'nyye kanaly (KMK). Materialy Resp. nauchno-praktich.konf. «Problemy i zadachi tselevogo i effektivnogo ispol'zovaniya vodnykh resursov fermerskimi khozyaystvami». 2009. Pp. 147-150.

25. Krutov A., Norkulov B., Artikbekova F., Nurmatov P. Optimal location of an intake at a reservoir prone to salt diffusion. IOP Conf. Ser. Mater. Sci. Eng. 869(7), 072020, (2020)

26. Krutov A., Norkulov B., Nurmatov P., Mirzaev M. Applicability of zero-dimensional equations to forecast nonconservative components concentration in water bodies. IOP Conf. Ser. Mater. Sci. Eng. 883(1), 012028 (2020)

27. Bekchanov, F., Ergashev, R., Mavlanov, T., Glovatskiy, O. Mathematical model of vibrating air pump unit, E3S Web of Conferences, 97, 05045, (2019)

28 Glovatskii, O.Ya., Ergashev, R.R., Bekchanov, F.A., Sharipov, S.M. Hybrid installations in pumping stations based on the use of renewable energy sources, Applied Solar Energy (English translation of Geliotekhnika), 48(4), pp. 266-268, (2012)

29. Uralov B., Rakhmatov N., Khidirov S., Uljaev F., Raimova I. Hydraulic modes of damless water intake, IOP Conf. Ser. Mater. Sci. Eng. 1030(1), 012123 (2021) 